\title{
Impact of predation by greater flamingos Phoenicopterus ruber on the macrofauna of two southern African lagoons
}

\author{
D. Glassom*, G. M. Branch \\ Zoology Department, University of Cape Town, Rondebosch 7700, South Africa
}

\begin{abstract}
Greater flamingos Phoenicopterus ruber were excluded from intertidal areas of one lagoon and intertidal and subtidal areas of another, both on the Namibian coast. Macrofaunal numbers increased at all exclusion sites, reaching approxımately 3 times the density of control plots subtidally, and 1.5 times the control density intertıdally. Only 1 species, the polychaete Diopatra neapolitana, decreased in abundance inside cages. Both intertidal sites were polychaete dominated; subtidally, ampeliscid amphipods dominated and tormed dense tube-mats that covered the substrate. Despite differences in macrofaunal abundance between treatments, diversity indices wert: smimar Overall, $P$. ruber have a major effect on macrofauna at these lagoons. In their absence, physical factors may play an important role.
\end{abstract}

KEY WORDS: Flamingo $\cdot$ Lagoon $\cdot$ Macrofauna

\section{INTRODUCTION}

Peterson (1977) has stated 'a major goal in the study of any ecological community is to achieve an appreciation for the dominant force or forces involved in community organisation'. Much of the literature on the benthos of both hard and soft marine substrates reflects this goal (e.g. Bell 1980. Van Blaricom 1982, Alongi 1985, Brey 1991). Workers on rocky marine communities have had considerable success in elucjdating such forces-rocky shore communities are powerfully influenced by intense competition for space, with one or a few species tending to dominate any particular zone. This competition may be mediated by physical or biological disturbance, including predation (Paine 1974, Peterson 1979), and may vary according to the predictability and intensity of recruitment (Menge \& Sutherland 1987). However, problems associated with working in soft substrates, particularly in estuaries and lagoons, have hindered similar progress

•E-mail: dglassom@botzoo.uct.ac.za in the study of soft-sediment communities (Dayton 1984). While competition has often been cited as being important (e.g. Johnson 1970, Grassle \& Sanders 1973), and sometimes demonstrated as a structuring force in marine soft-bottom communities (Woodin 1974, Peterson 1977), it clearly does not account adequately for community structure in the majority of cases (Black \& Peterson 1988).

Virnstein (1977) demonstrated that in the absence of predation in soft sediments, an opportunistic, colonising species (the bivalve Mulinia lateralis) could persist at high densities and even exclude other species. although the mechanism of such exclusion may have been incidental predation on settling larvae or an amensalistic interaction rather than competition. He suggested that some species may be excluded because they are poor 'predation avoiders', rather than poor resource competitors. Peterson (1979), in a review of studies of predator exclusion in soft sediments, failed to find any cases in which the community tended toward competitive dominance by single species. Other authors (e.g. Virnstein 1978, Quammen 1984 Wilson 1989) who have conducted predator exclusion experiments, similarly reported an absence of compet- 
itive exclusion, even where infauna occurred at high densities.

Apart from competition, disturbance (including predation) is the force most often presumed to affect community structure in soft sediments (Brey 1991). A feature of soft sediments is that any epibenthic predator feeding on the infauna is almost bound to cause a significant disturbance to the substrate. The 2 effects are therefore often difficult to distinguish, and many studies treat them as one (e.g. Oliver et al. 1985, Thrush 1986, Hall et al. 1990a, Thrush et al. 1991, Webb \& Parsons 1991). Exceptions are Virnstein (1977) and Kneib (1988) who managed to separate the impacts of physical and biological processes. Predation can be an important organising force of soft-sediment communities (Bell 1980), but unlike the situation on rocky shores, its main effect is not in mediating interspecific competition (Dayton 1984). Nevertheless, it is apparent that both physical and biologically caused disturbances are integral to the organisation of marine softbottom communities (Reidenauer \& Thistle 1981).

The mechanisms by which disturbances act on marine soft-sediment communities are diverse and may include freeing of space for larval recruitment, reduction of competition, or alteration of resources to allow colonisation by opportunist species (Thistle 1981). Almost all studies of biological disturbance of or predation effects on community structure use some form of exclosures to exclude a particular predator or group of predators, or to manipulate the densities of predators or competitors. However, caging manipulations can create undesirable side effects which make interpretation of results difficult. For example, sampling disturbance is always a factor. Structures on the sediment surface, such as exclosures, are likely to trap drifting algae and to attract fauna in much the same way as a reef would. Trapped algae may decay, causing anoxic conditions inside exclosures (Arntz 1977). Currents within cages are likely to differ from those outside, and this may lead to either sedimentation or scouring (Virnstein 1978), modifying the potential settling of planktonic larvae. Predators entering the cage as larvae or juveniles may confound the results of the experiment. Finally, it may be difficult to prevent predators from gaining access because they may burrow under the edge of a cage. Baird et al. (1985) have criticised caging manipulations on the additional grounds that emigration from exclosures may occur as a means of avoiding intraspecific competition as densities increase within exclosures. Further, growth of animals over the duration of the experiment may mean that some individuals which were not retained in sieves at the beginning of the experiment may be retained toward the end. Either of these occurrences would lead to the underestimation of losses to preda- tion. As a consequence, Baird et al. (1985) argue that direct measurement of consumption by predators or estimation of their daily energy requirements are more accurate means of estimating predation impacts on benthic communities. However, Hall et al. (1990b) point out that energy flow in a predator-prey interaction may have little bearing on the functional importance of that relationship to the community, and that in the absence of predation, similar mortalities may be caused by other density dependent effects. They conclude that energetics studies may be of little value in estimating predator effects, and that field experiments are the least equivocal way of measuring such effects.

Thus, despite potential problems, caging manipulations remain the most viable method for studying the effects of predators on soft-sediment communities, particularly when they are employed with prudent controls.

Several workers have studied the effects of shorebird predation or disturbance on the benthic communities of soft sediments. Among these, results differ considerably. Reise (1978) and Raffaelli \& Milne (1987) found that large epibenthic predators, including shorebirds, have little effect on prey abundance compared to the effects of smaller invertebrate predators. In contrast, Bengtson (1976) showed that shorebirds considerably reduced densities of prey species. Quammen $(1981,1984)$ found that shorebirds could substantially affect abundances of invertebrate fauna in muddy substrates.

Curiously, little attention has been paid to the potential effects of the greater flamingo Phoenicopterus ruber, although Hurlbert \& Chang (1983) did investigate the grazing effect of Phoenicoparrus andinus on the microbenthos of a lake.

Flamingos often occur at high densities, and their large size implies high impacts on prey species. Furthermore, they substantially affect subtidal as well as intertidal benthic communities. Greater flamingos filter-feed on small invertebrates in shallow water, either by sweeping their beaks in an arc as they walk, or more commonly by using a circular jogging motion to suspend sediment while remaining in one spot ('walk feeding' and 'stamp feeding' respectively, in the terminology of Bildstein et al. 1991). When the latter method of feeding is employed, large ring-like depressions (approximately $1 \mathrm{~m}$ diameter) are left in the sediment. Where high numbers of flamingos occur, the entire topography of large areas of the sediment can be altered.

At 2 lagoons on the coastline of Namibia, Walvis Bay $\left(22^{\circ} 58^{\prime} \mathrm{S}, 14^{\circ} 29^{\prime} \mathrm{E}\right)$ and Sandwich Harbour $\left(23^{\circ} 22^{\prime} \mathrm{S}\right.$, $14^{\circ} 30^{\prime} \mathrm{E}$ ), flocks of greater (Phoenicopterus ruber) and lesser ( $P$. minor) flamingos are resident, leaving only at irregular intervals to breed inland. They are absent 
from approximately January to April after which they return with their young At both sites, the birds feed subtidally and in unvegetated intertidal areas, and their trademark 'wheelies' are a prominent and persistent feature of the mud-flats.

The 2 lagoons provided interesting comparative study sites for a number of reasons. They are close to each other, separated by no more than $50 \mathrm{~km}$. Neither lagoon has any significant freshwater inflow. Walvis Bay is a premier site for waders on the southern African coastline (Hockey \& Bosman 1983). The lagoon adjoins a major harbour, and is surrounded by industrial salt pans. No vegetation occurs in the lagoon. Sandwich Harbour is a nature reserve, accessible to the public only on a daily walk-in basis. At the time of the study, the northern end of the lagoon was vegetated with reeds and spartina beds, but the channels of water flow were bordered by unvegetated mud, where the flamingos fed. During the study undertaken, approximately 30000 flamingos were resident at Walvis Bay, of which an estimated 12000 were greater flamingos. At Sandwich Harbour, the number of flamingos varied during the study, but never exceeded 500 greater flamingos

The present study was designed to quantify the disturbance/predation effects of greater flamingos on the benthic macrofauna of these 2 lagoons, using caging manipulations. At Walvis Bay the effects of flamingos were investigated subtidally and intertidally, but at Sandwich Harbour caging manipulations were confined to the intertidal zone. A companion paper (Glassom \& Branch 1997) will explore the effects of flamingos on meiofauna, microflora and on the physical properties of the affected sediments.

\section{METHODS}

In total, 3 sets of 4 exclosures each were erected. At Walvis Bay, 1 set of cages was established intertidally and 1 subtidally. At Sandwich Harbour, only intertidal cages were built

Each exclosure measured $3.5 \times 3.5 \mathrm{~m}$, and consisted of 8 upright stakes, with 2 strands of rope stretched tautly between them. Mesh was unnecessary, due to the size of the predator being excluded, avoiding many problems normally encountered in caging manipulations. The design excluded only flamingos, while allowing access to smaller animals such as waders and fish. While lesser flamingos were also inevitably excluded, they are water-column feeders (Jenkin 1957), eat mostly algae (Brown 1959) and cause little disturbance to the sediment. It was therefore deemed unlikely that their exclusion would have a major effect on the results of the experiment. The poles of the cages were hammered into the sediment to a depth of $40 \mathrm{~cm}$ and stood $140 \mathrm{~cm}$ proud of the surface. Flat plastic discs with holes in the centre were placed over each pole and pressed firmly into the sediment, helping to prevent scouring from around the poles. In order to minimize the possibility of bias due to edge effects or to nutrient enrichment due to guano from birds perching on the cages, a margin of $0.5 \mathrm{~m}$ was left unsampled around the inside edge of the exclosures. On each occasion, samples were taken from a different position within the cages, at a sufficient distance to assure independence. Care was taken to avoid sampling areas that might have been disturbed by trampling during previous sampling.

There were 4 replicate control areas for each set of cages. Control areas were unmarked, but alternated with cages and were positioned at the same tidal level. This method of choosing control areas was used because it was felt that interspersion of treatments was more important than their random assignment for this type of experiment. For each control plot, 3 subsamples were taken randomly within an area approximating that of the cages. No effort was made to specifically avoid or sample humps or pits in disturbed areas, and any preference of fauna for these microhabitats should not therefore have biased the results

No separate structures were erected to study cage effects (i.e. cage controls). Rather, half the cages were partially dismantled at each site on the penultimate sampling date and resampled on the last date, when they were compared with both full cages and controls Intertidally at Walvis Bay, the remaining cages disappeared between these 2 dates. This meant that no data were obtained for cage controls for this site.

The first set of cages was erected intertidally at Walvis Bay in April 1989. Samples were taken immediately after the cages were erected, 1 wk later and 2 wk after that. Further samples were taken in July 1989 then at 3-monthly intervals until the experiment was terminated in July 1990. The subtidal exclosures were erected in May 1989, coinciding with the third set of intertidal samples collected, and subsequent samples were taken at the same times as those of the intertidal. Sandwich Harbour is a nature reserve, and the caging manipulations at Sandwich Harbour could only be initiated in October 1989 when a permit was issued.

Three subsamples were collected on each sampling date for each cage and each control. Intertidal macrofaunal samples were taken by marking an area of $0.1 \mathrm{~m}^{2}$, removing the sediment to a depth of $20 \mathrm{~cm}$ and sieving it through $1 \mathrm{~mm}$ mesh. Subtidally, a core of $13 \mathrm{~cm}$ diameter was used for all macrofauna. Animals were either sorted by hand, or were 'floated' out. The latter method is less desirable, as it may underestimate bivalves, but was necessary when large numbers of 
amphipod tubes made hand-sorting impractical. Macrofauna were identified to species level where possible and counted.

Tests for treatment effects were done using nested ANOVAs (Underwood 1981) in the generalised linear modelling (GLM) procedure of the program SAS, which is designed to handle unbalanced data sets. 'Date' was analysed as a main effect and for its interaction with 'treatment', effectively giving a repeated measures analysis. Statistical tests for treatment differences were carried out only on species with densities which exceeded 1 animal $\mathrm{m}^{-2}$ and which occurred regularly in samples. Data were logtransformed as necessary, to ensure homoscedasticity. Where relevant, contrast was used in preference to multiple comparison tests. This allows specific hypotheses to be tested, can be performed on nested data, and is more powerful than most other tests (Freund et al. 1986)

All error bars on the figures represent the calculated standard errors of the data. For Walvis Bay intertidal the term 'initial' on the graphs indicates samples that were taken immediately after erection of the exclosures.
Shannon-Wiener diversity indices were calculated for macrofauna at all sites, and compared between treatments and controls using appropriate $t$-tests (Zar 1984).

\section{RESULTS}

\section{Topographic change}

Changes to the sediment surface were visible within 3 mo of initiating the experiments. Intertidally, the sediment inside exclosures became smooth and uniformly tan. There was no sign of flamingo feeding, but wader tracks were common. Outside exclosures, perturbations caused by flamingos were still clearly visible. Direct observation using snorkeling gear at high tide confirmed that fish were feeding within exclosures. The exclosures were thus successful in excluding flamingos while allowing access to other species.

Subtidally at Walvis Bay, the sediment inside caged areas became dominated by dense tube mats, built mainly by ampeliscid amphipods. Tubes of the polychaete Capitella capitata were also present. In 2 of the

Table 1. Macrofauna abundances in exclosures (Excl) and in controls (Con) for all 3 sites. Means (no. $\mathrm{m}^{-2}$ ) are for the entire duration of the experiment. ANOVAs were performed for treatment and date effects for all species with means $>1$ animal m ${ }^{-2} F$ and $\mathrm{p}$ values shown are for treatment effects. A: species absent from site. ${ }^{-S i g n i f i c a n t ~ i n t e r a c t i o n ~ b e t w e e n ~ d a t e ~ a n d ~ t r e a t m e n t ~}$

\begin{tabular}{|c|c|c|c|c|c|c|c|c|c|c|c|c|}
\hline & \multicolumn{8}{|c|}{ Walvis Bay } & \multicolumn{4}{|c|}{ Sandwich Harbour } \\
\hline & \multirow{3}{*}{ Excl } & \multicolumn{3}{|c|}{ Intertidal } & \multirow{3}{*}{ Excl } & \multicolumn{3}{|c|}{ Subtidal } & \multirow{3}{*}{$\mathrm{Excl}$} & \multirow{3}{*}{ Con } & \multirow{2}{*}{\multicolumn{2}{|c|}{ ANOVA }} \\
\hline & & Con & AN & OVA & & Con & AN & OVA & & & & \\
\hline & & & $F$ & $\mathrm{p}$ & & & $F$ & $\mathrm{p}$ & & & $F$ & $\mathrm{p}$ \\
\hline \multicolumn{13}{|l|}{ Polychaeta } \\
\hline Prionospio sexoculata & 28 & 30 & 0.02 & 0.89 & 884 & 21.7 & 3.35 & 0.071 & $A$ & A & - & - \\
\hline Capitella capitata & 2206 & 1426 & 16.88 & 0.0001 & 11013 & 4137 & 35.85 & $0.0001^{\circ}$ & 1320 & 807 & 4.79 & 0.033 \\
\hline Desdemona ornata & 11 & 3 & 19.3 & $0.0001^{\circ}$ & 1914 & 124 & 5.48 & 0.02 & A & A & - & - \\
\hline Boccardia polybranchia & $A$ & A & - & - & A & A & - & - & 238 & 78 & 5.65 & 0.002 \\
\hline Diopatra neapolitana & $<1$ & $<1$ & - & - & 15 & 89 & 8.02 & 0.006 & $<1$ & $<1$ & - & - \\
\hline Nereis falsa & A & A. & - & - & A & A & - & - & $<1$ & $<1$ & - & - \\
\hline Nereis succinea & A & A & - & - & A & A & - & - & $<1$ & $<1$ & - & - \\
\hline \multicolumn{13}{|l|}{ Nemertea } \\
\hline Cerebratulus fuscus & A & $\mathrm{A}$ & - & - & 21 & 36 & 0.35 & 0.550 & 27 & 15 & 9.34 & $0.004^{\circ}$ \\
\hline Oligochaeta & $<1$ & $<1$ & - & - & $<1$ & $<1$ & - & - & 139 & 53 & 8.34 & 0.006 \\
\hline Phoronida & A & A. & - & - & $\mathrm{A}$ & A & - & - & $<1$ & $<1$ & - & - \\
\hline \multicolumn{13}{|l|}{ Mollusca } \\
\hline Dosinia lupinus & $\mathrm{A}$ & $\mathrm{A}$ & - & - & A & A & - & - & 9 & 11 & 0.03 & 0.890 \\
\hline Small unid. bivalve & 82 & 45 & 0.13 & 0.727 & 18 & 2 & 0.93 & 0.530 & 143 & 147 & 2.08 & 0.155 \\
\hline \multicolumn{13}{|l|}{ Crustacea } \\
\hline Hymenosoma orbiculare & 3 & 1 & 0.25 & 0.626 & 11 & 6 & 0.42 & $0.516^{*}$ & $<1$ & $<1$ & - & - \\
\hline Ampelisca brevicornis & 12 & 6 & 0.03 & $0.912^{\circ}$ & 11624 & 4602 & 4.40 & $0.039^{\circ}$ & 12 & 8 & 0.25 & 0.617 \\
\hline Ampelisca palmata & 95 & 29 & 9.22 & $0.003^{\circ}$ & 18820 & 5077 & 36.92 & $0.0001^{\circ}$ & 25 & 19 & 5.29 & 0.025 \\
\hline Lemboides sp. & $<1$ & $<1$ & - & - & 1262 & 469 & 4.26 & $0.042^{\circ}$ & 1 & 2 & 0.04 & 0.839 \\
\hline Paridotea ungulata & A & A & - & - & $<1$ & $<1$ & - & - & A & $A$ & - & - \\
\hline \multicolumn{13}{|l|}{ Pisces } \\
\hline Ophisurus serpens & $\mathrm{A}$ & A & - & - & $<1$ & $<1$ & - & - & $<1$ & $<1$ & - & - \\
\hline Total macrofauna & 2437 & 1542 & 33.57 & 0.0001 & 45594 & 14772 & 57.96 & $0.0001^{\circ}$ & 191.4 & 1141 & 17.19 & 0.001 \\
\hline
\end{tabular}


cages, these mats were so dense that the sediment surface was raised above the water surface at low tides.

\section{Overall macrofaunal response}

In total, 18 species were collected at the 3 sites. Of these, 15 occurred at Sandwich Harbour, 13 at Walvis Bay subtidal and 10 at Walvis Bay intertidal. Of 25 instances where data were tested, 17 of the species showed significant differences between treatments (Table 1). Almost all species increased in density within exclosures, but a few decreased, notably the polychaete Diopatra neapolitana at Walvis Bay subtidal. All other polychaete species increased in exclusion areas, or in rare cases showed no response. The nemertean Cerebratulus fuscus decreased in density inside exclosures at Walvis Bay subtidal, but increased in those at Sandwich Harbour All amphipods which were sufficiently abundant to warrant examination increased in exclosures relative to control areas. Total macrofaunal density increased within exclosures at all sites.

\section{Responses of individual species}

Capitella capitata was the most abundant polychaete at all sites. Its numbers were consistently higher in cages than in controls, and this difference tended to become more pronounced with time (Fig. 1). Prionospio sexoculata and Desdemona ornata were common at Walvis Bay, but were replaced by Boccardia polybranchia (Fig. 2) at Sandwich Ilarbour. With the exception of $P$. sexoculata at Walvis Bay intertidal, all 3 increased in abundance inside exclosures. As with $C$. capitata, the relative difference between caged and control areas increased over time for B. polybranchia and $D$. ornata. The large tube-building polychaete Diopatra neapolitana (Fig. 3j occurred at all sites, but was abundant only subtidally, where caging had a consistently negative effect on its density.

An unidentified oligochaete, common at Sandwich Harbour, was rare at the other 2 sites. The nemertean worm Cerebratulus fuscus, in contrast, occurred at Sandwich Harbour and subtidally at Walvis Bay, but was entirely absent intertidally at Walvis Bay. Both species increased significantly in abundance in cages relative to controls at Sandwich Harbour C. fuscus did not respond significantly to treatment at Walvis Bay subtidal

Two species of bivalve were collected. The first, an unidentified small ( 1 to $2 \mathrm{~mm}$ ), white bivalve, was common at all 3 sites, but could not be accurately quantified on the dates when fauna was sorted by floating.

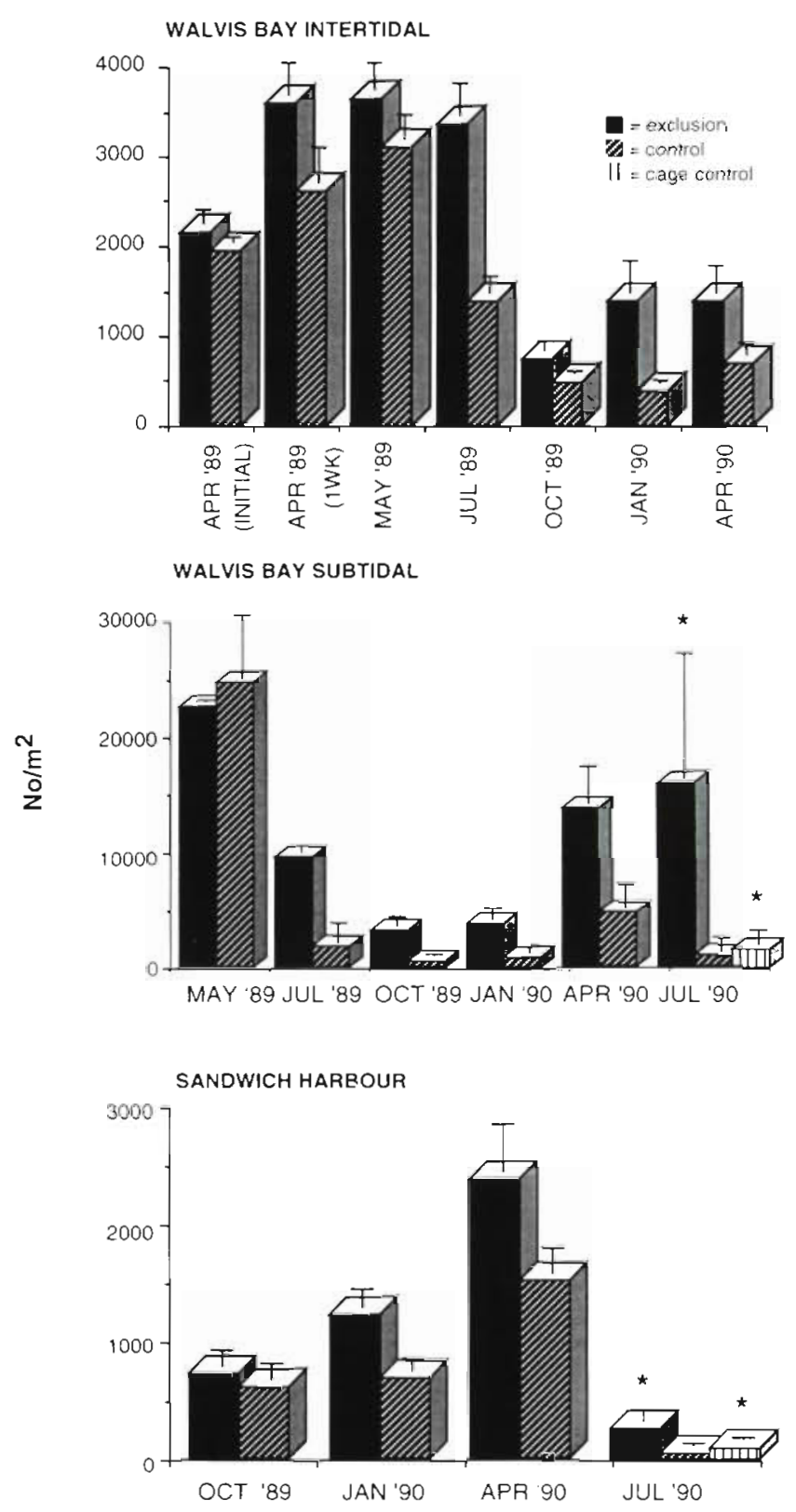

Fig. 1. Capitella capttata. Density at all 3 sites. Values are means + SE. $n=4$, except for * where $n=2$

For this reason, data were not available for this species on all dates. The second, Dosinia lupinus, was found only at Sandwich, reaching a density of ca $10 \mathrm{~m}^{-2}$. The unidentified species increased rapidly inside exclosures at Walvis Bay intertidal during the early phase of the experiment, but could not be accurately counted thereafter No clear patterns were apparent for either species at Sandwich Harbour.

The common crustacean fauna comprised 3 species of amphipod and $1 \mathrm{crab}$. The crab, Hymenosoma orbiculare, was commonly found at both sites at Walvis Bay, 


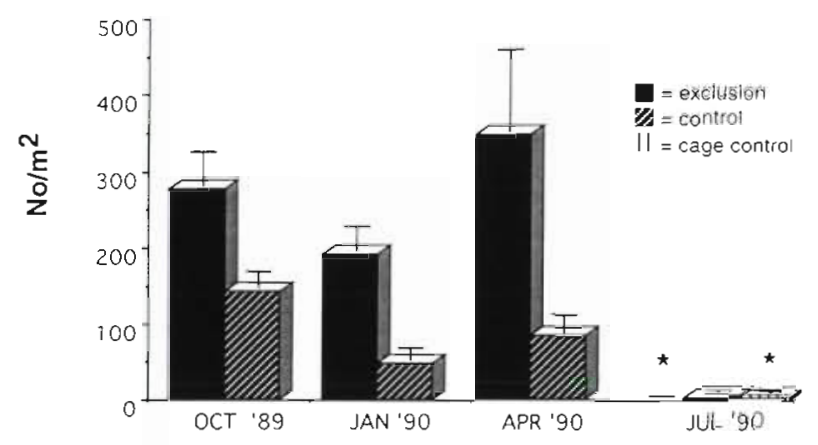

Fig. 2. Boccardia polybranchia. Density at Sandwich Harbour. Values are means + SE. $n=4$, except for ${ }^{*}$ where $n=2$

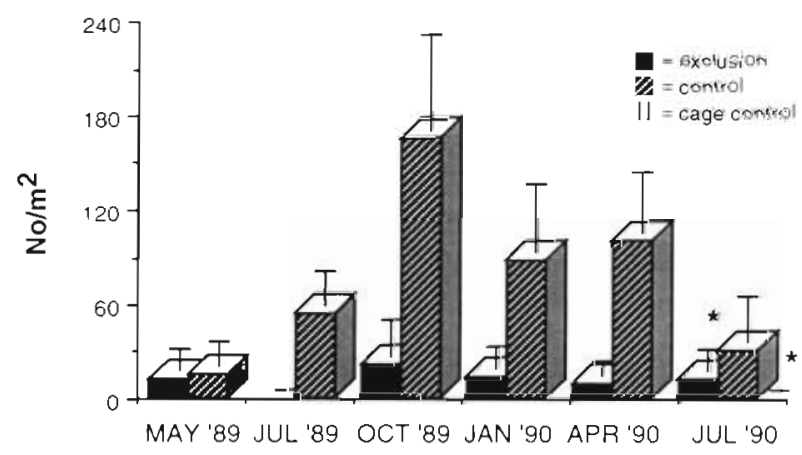

Fig. 3. Diopatra neapolitana. Subtidal density at Walvis Bay. Values are means + SE. $n=4$, except for * where $n=2$

but rarely at Sandwich Harbour. All $H$. orbiculare found were juveniles ( 3 to $10 \mathrm{~mm}$ carapace width). The adults prefer sandier substrata, and were not found in the muddier areas where flamingos forage. All 3 amphipod species occurred at all sites, although the Lemboides sp. occurred at very low density intertidally at Walvis Bay. At all sites, Ampelisca palmata was the most common amphipod, and Lemboides sp. the rarest. Both species of Ampelisca increased in numbers in exclosures at all sites, but this was most obvious at Walvis Bay subtidal, where they were extremely abundant (Figs. 4 \& 5) and the substrate became completely dominated by amphipod and polychaete tubes.

Total macrofaunal density (Fig. 6) was consistently higher in exclosures than in control areas at all sites.

A notable feature of many macrofaunal species was their decrease over time during the study, regardless of treatment. This is exemplified by the amphipods, almost none of which were recorded at Walvis Bay intertidal after October 1989. The same trend was apparent with some of the polychaete species and is reflected in the change in total macrofaunal density over time, particularly at Walvis Bay intertidal (Fig. 6).

Both the intertidal sites were polychaete dominated, with Capitella capitata comprising 70 to $80 \%$
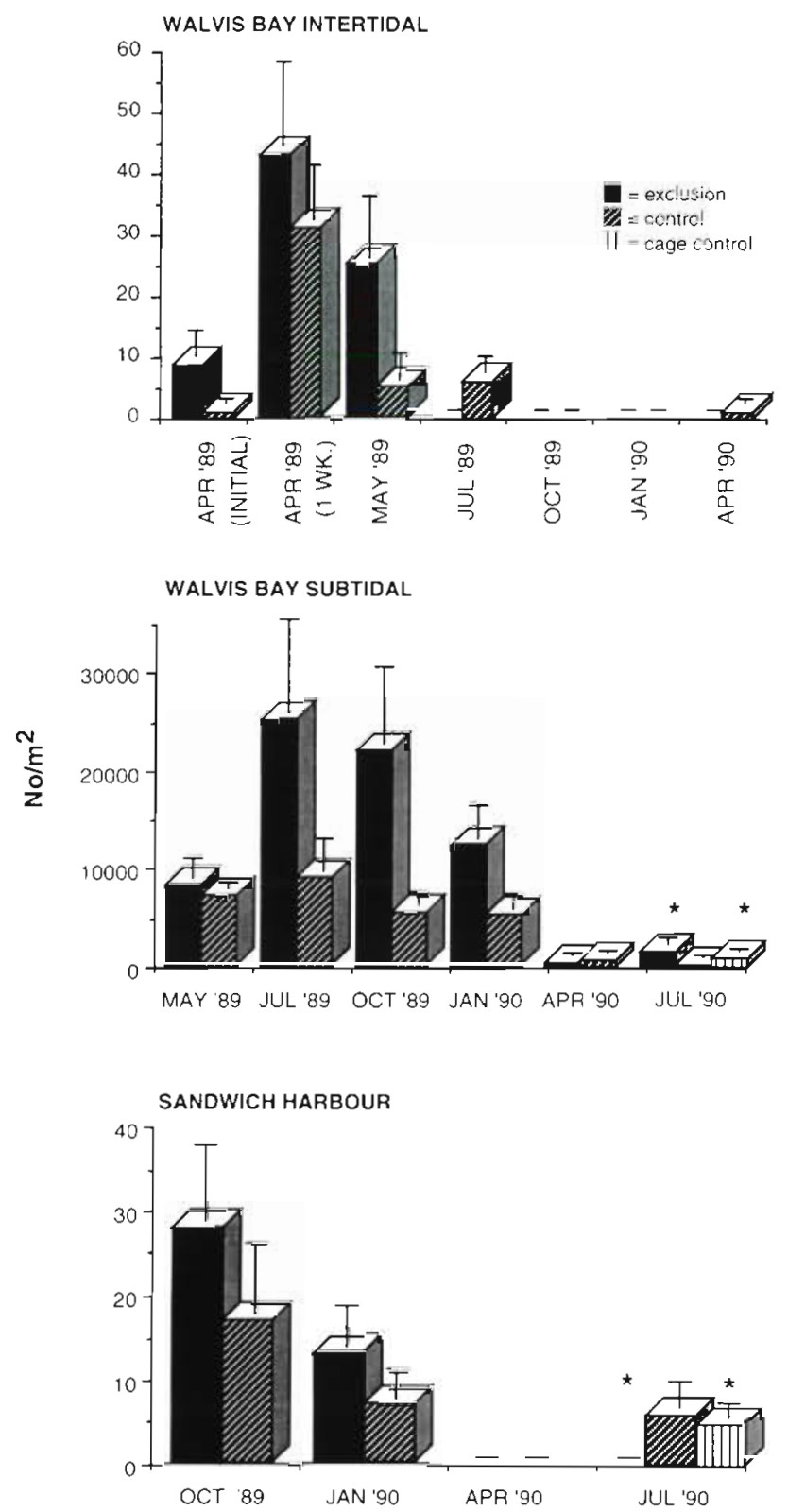

Fig. 4. Ampelisca brevicornis. Density at all 3 sites. Values are means + SE. $n=4$, except for * where $n=2$

of the faunal density at these sites (Fig. 7). At both sites, the relative abundance of $C$. capitata decreased slightly in exclusion areas. Walvis Bay subtidal was dominated by amphipods rather than polychaetes, with Ampelisca palmata constituting ca $40 \%$ of the fauna in exclosures. The proportions of $A$. brevicornis and $C$. capitata decreased slightly in exclosures compared to control areas. Despite these minor changes, however, the most striking feature was that the relative proportions of species in control and experimental plots remained remarkably similar (Fig. 7). In spite 

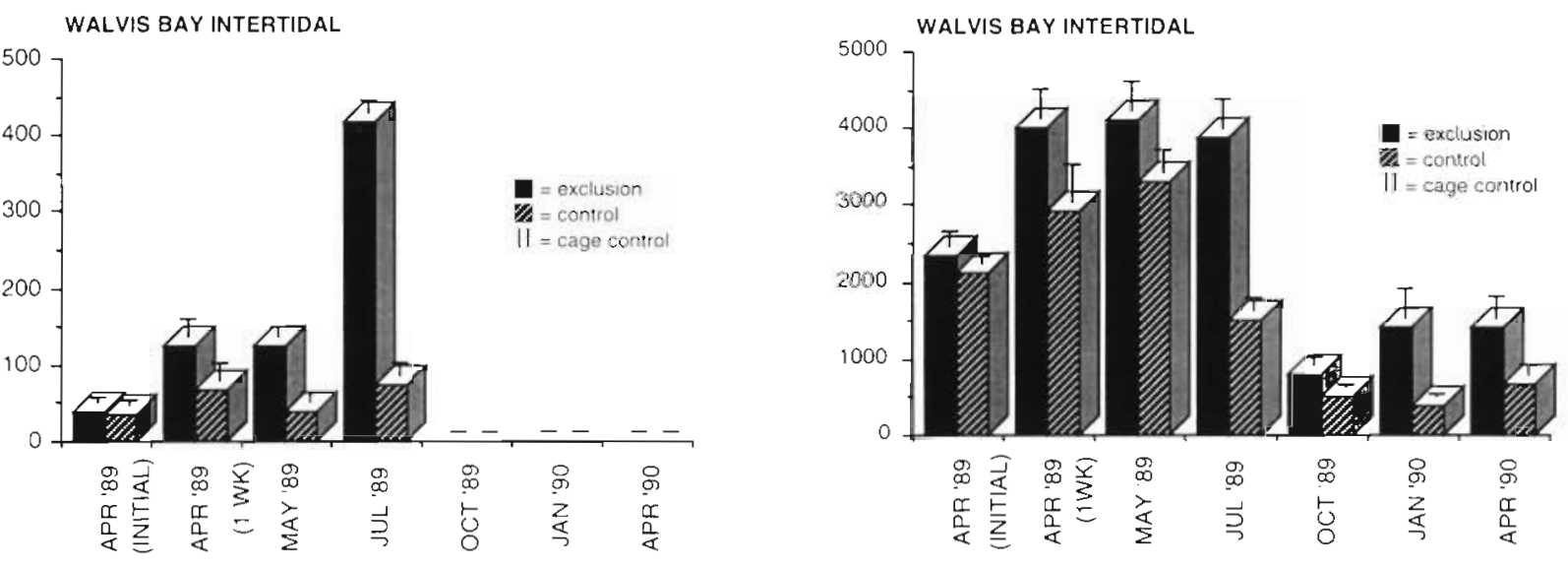

WALVIS BAY SUBTIDAL
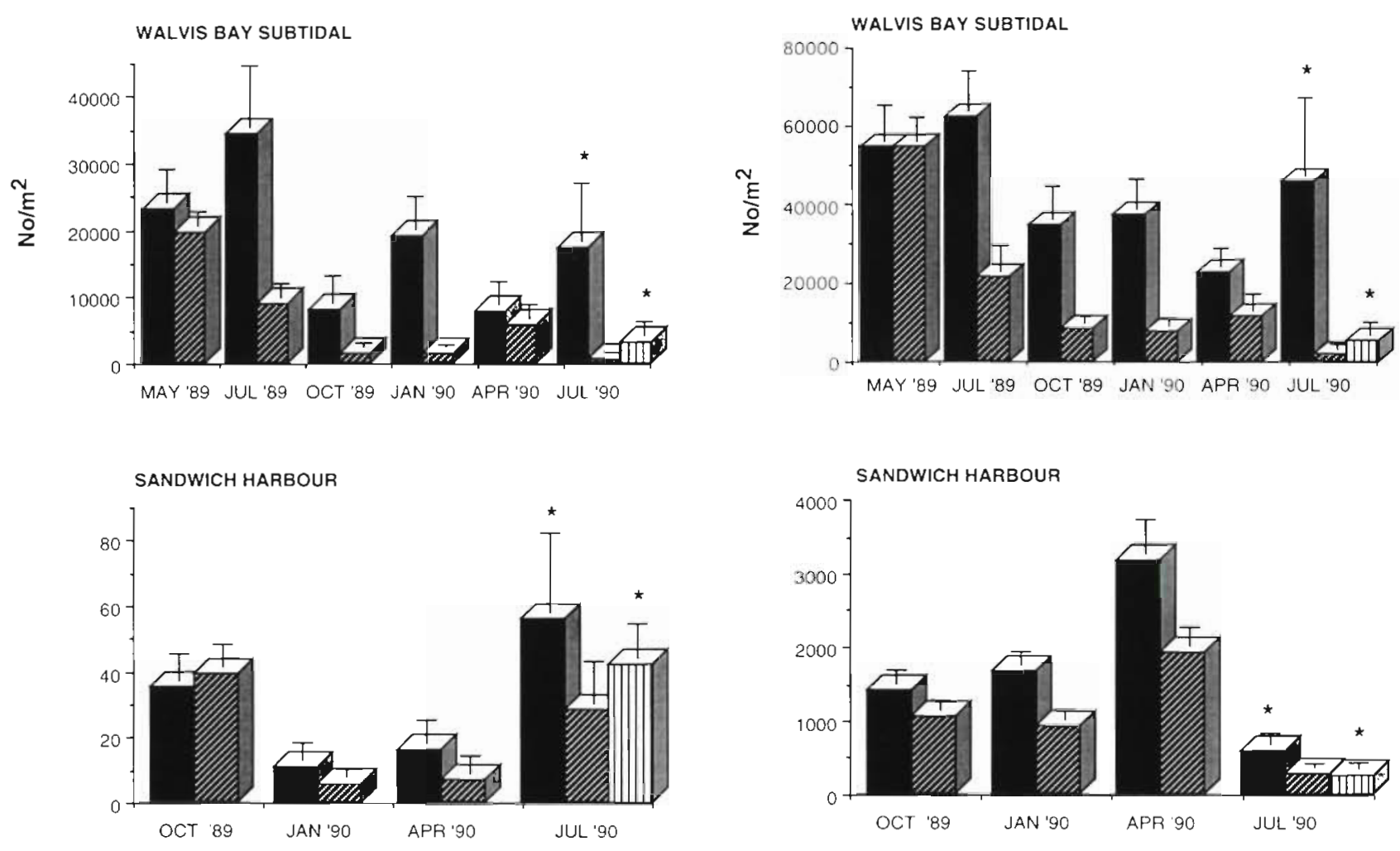

Fig. 5. Ampelisca palmata. Density at all 3 sites. Values are means $+\mathrm{SE} . \mathrm{n}=4$, except for * where $\mathrm{n}=2$

of substantial increases in density resulting from exclusion of flamingos, proportions of the species and indices of diversity and evenness showed no differences between treatments and controls at any site (Table 2).

\section{Cage controls}

In July 1990, abundances of macrofaunal species were compared between cage controls, full cages and

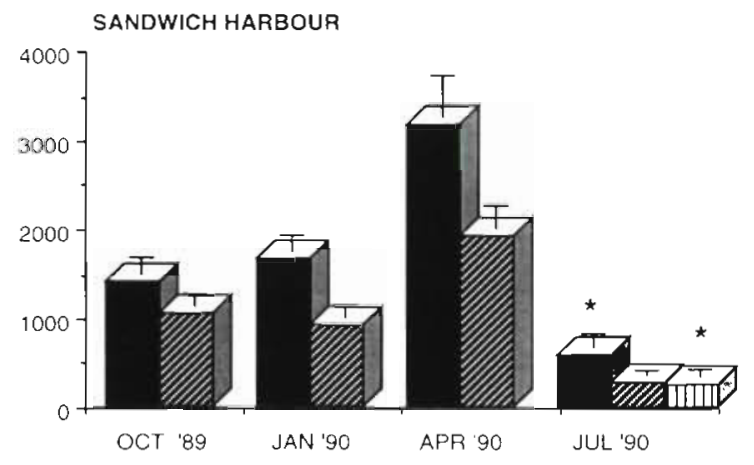

Fig. 6. Total macrofaunal density at all 3 sites. Values are means + SE. $n=4$, except for * where $n=2$

control areas, using Contrast. In part due to a decrease in overall macrofaunal numbers at Walvis Bay, some differences may have been hidden, and 9 taxa showed no difference between treatments for that date. Of the 10 cases where differences were apparent, cage controls and controls grouped together and were significantly different from exclusion areas in 9 cases $(p<$ 0.05). In only 1 instance (Ampelisca brevicornis at Walvis Bay subtidal) were exclusion and cage control values unequivocally grouped and significantly different from the contral. 


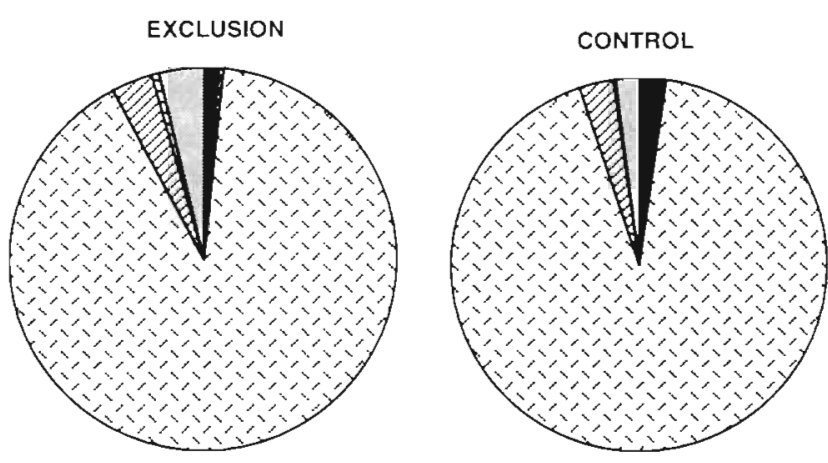

WALVIS BAY INTERTIDAL
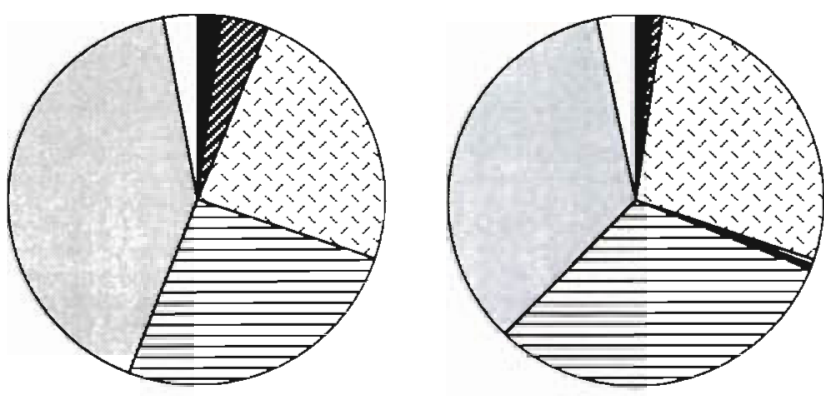

WALVIS BAY SUBTIDAL
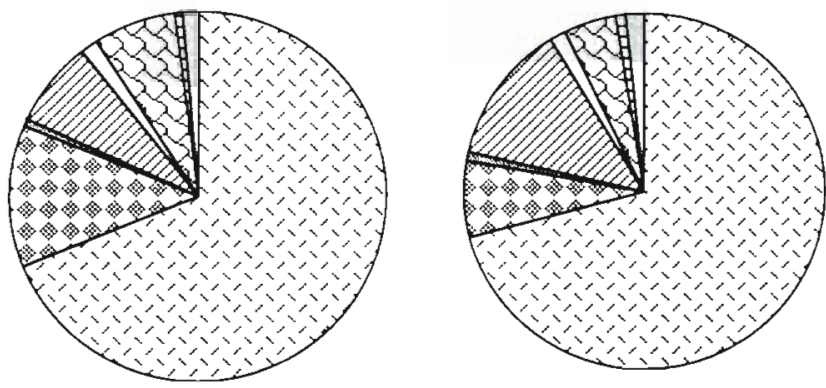

SANDWICH HARBOUR

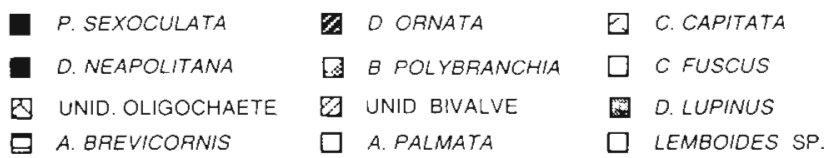

Fig. 7 Relative abundance of macrofaunal species over the duration of the study

\section{DISCUSSION}

\section{Cage controls}

Adequate controls for the effects of caging on soft sediments have long been problematic (Peterson 1979). This problem is often approached by erecting sets of partial cages which ostensibly mimic cage effects, but do not exclude the species being manipulated (e.g. Quammen 1984, Frid \& James 1988). Another approach (e.g. Bell 1980) is to monitor areas after partially dismantling existing exclosures. Faunal densities within partially dismantled structures should return to background (control) levels. These approaches are contingent on the assumption that the species being excluded will not react adversely to the presence of partial cages. This assumption is not necessarily correct for sophisticated predators such as birds (e.g Frid \& James 1988). We could not be sure that flamingos fed at the same intensity within partial cages as in completely open control areas.

The exclosures themselves were designed to minimise cage effects. During the experiment, no signs of scouring or siltation were evident in the cages and no weed or other organic matter clogged the ropes due to the distance between the strands. These observations, as well as the fact that cage controls yielded results similar to controls in 9 of 10 areas where any differences were apparent, strongly indicate that caging had no adverse side-effects that may have clouded interpretation of the effects of flamingo exclusion. This conclusion is robust: if the flamingos did feed less in cage controls than in open areas, this could only have incorrectly inferred a caging effect.

\section{General responses of macrofauna}

Macrofauna generally became more abundant inside exclosures. However, a notable phenomenon in the study was the apparent decline in abundance of some species over time, regardless of treatment. Particularly affected were amphipods and the polychaete Prionospio sexoculata at Walvis Bay. Some of these

Table 2. Comparison of Shannon-Wiener diversity indices $\left(H^{\prime}\right)$ and evenness $(E)$ between treatments and controls for all sites. t-tests for diversity indices (Zar 1984) were used. $H^{\prime}$ was calculated for all dates excluding first sampling date at each site Sample sizes were 20 at Walvis Bay intertidal, 18 at Walvis Bay subtidal and 10 at Sandwich Harbour

\begin{tabular}{|c|c|c|c|c|c|c|}
\hline \multirow[t]{2}{*}{ Site } & \multicolumn{2}{|c|}{ Exclusion } & \multicolumn{2}{|c|}{ Control } & \multirow[t]{2}{*}{$t$} & \multirow[t]{2}{*}{ p } \\
\hline & $H^{\prime}$ & E & $H^{\prime}$ & $E$ & & \\
\hline Walvis Bay intertidal & 0.440 & 0.176 & 0.443 & 0.196 & 0.008 & $1>p>0.5$ \\
\hline Walvis Bay subtidal & 1.455 & 0.492 & 1.659 & 0.522 & 0.3609 & $1>p>0.5$ \\
\hline Sandwich Harbour intertida! & 1.540 & 0.549 & 1.542 & 0.524 & 0.0022 & $1>p>0.5$ \\
\hline
\end{tabular}


species were totally absent from samples taken during the later phases of the study (Figs. $4 \& 5$ ). This did not seem to be a seasonal occurrence, since these species were abundant during comparable seasons the previous year. Increased predation pressure or densitydependent mortalities are unlikely because the event was not treatment specific. Furthermore, marine invertebrates are able to survive at high densities due to developmental plasticity (Peterson 1979), decreasing the likelihood of density-dependent mortality. The Namibian coastline is periodically subjected to sandstorms resulting from easterly Berg winds which pick up large quantities of sand as they cross the desert. Much of this load, which is rich in mica, is deposited at the coast. Although these winds contribute little to the annual aeolian sediment deposition in the lagoon (Anonymous 1989), they deposit large loads over short periods during autumn and winter (usually between April and July). This can reputedly cause anoxic sediment conditions that result in mass mortalities (Schalk De Witt pers comm.). Whether the decline in abundance of some macrofauna can be attributed to such an event is a matter of speculation. Nevertheless it may provide an example of episodic physical disturbance profoundly influencing the biota of a lagoon, and invites further investigation.

Despite the decrease in macrofaunal density, dense mats of amphipod tubes persisted in subtidal exclosures until the end of the experiment. These mats were, however, drastically reduced in partially dismantled cages, suggesting that sediment disturbance during flamingo foraging was responsible for their reduction in partial cages. Flamingo foraging could adversely affect tubebuilding amphipods and polychaetes by exposing them to predation or due to increased energy expenditure needed to rebuild tubes. These effects could be manifested as changes in growth rate or size structure rather than changes in abundance (e.g. Wilson 1989) and more detailed studies of population structure would be necessary to elucidate them.

In a review of caging experiments, Peterson (1979) found that the most common effect of excluding large predators from intertidal areas was that macroinfaunal density increased 2 to 3 times over their previous abundance. Of our 3 sites, only Walvis Bay subtidal conformed closely to this pattern. Both intertidal sites showed significant treatment effects on macrofauna, but of lesser magnitude. Virnstein (1977) suggested that predation might be more significant subtidally than intertidally, following a similar gradient to that hypothesized for most rocky shores by Connell (1972) who proposed that predation decreases in importance with tidal height. Our results support this thesis. Why this should be so is unclear One possibility is that predation is heavier subtidally, since predators have con- stant access to this area. At both the lagoons studied in this project, the water was shallow enough for flamingos to forage around the subtidal cages for the majority of the time, while the opportunity to forage intertidally was limited to high tides. It is also possible that flamingos selectively forage in subtidal areas, since macrofaunal densities are higher subtidally.

In a few cases, exclusion of flamingos led to decreases in the densities of a few species of macrofauna. Most notable was the density of the large polychaete Diopatra neapolitana at Walvis Bay subtidal which was significantly higher in control areas than in cages. Fig. 3 shows that this is due to increased abundance in control areas rather than declining abundance in exclosures. Reise $(1978,1985)$ found that excluding fish and birds from areas of tidal flats of Königshafen, Germany, led to size-specific changes in abundance of fauna, with smaller macrofauna decreasing inside exclosures and larger fauna increasing In the present study, the only species to increase significantly in control areas, Diopatra neapolitana, was also the largest species present. Two other large species, Cerebratulus fuscus and Dosinia lupinus, were also less abundant inside cages, although not significantly so. This illustrates the varying effects of excluding different predators. Reise (1985) attributed the patterns found to preferential predation on large prey. In the present case, flamingos feed on small prey. Larger organisms are therefore not preyed on in control areas, and showed no sign of being adversely affected by sediment disturbance in these areas. Within exclosures, competition for space or the altered nature of the sediment, particularly subtidally, could have affected species such as $D$. neapolitana, accounting for the lower abundance.

As expected, abundance of macrofauna was much higher subtidally at Walvis Bay than at either intertidal site and the difference in abundance due to tidal levels overshadowed differences attributable to other properties of the sites. With regard to the intertidal sites, Walvis Bay had slightly higher densities of macrofauna in both control and exclusion areas than Sandwich Harbour. As an explanation, the former site had a higher proportion of Capitella capitata than the latter and this species can thrive in disturbed sediments. In the intertidal zone, species richness was highest at Sandwich Harbour but diversity $\left(H^{\prime}\right)$ was marginally higher in control areas at Walvis Bay subtidal than in the control sites at Sandwich Harbour Walvis Bay intertidal had the lowest species richness, diversity and evenness (Table 2). Expectations of higher diversity and richness at Sandwich Harbour were thus supported with regard to the 2 intertidal sites, but the difference between inter- and subtidal areas at Walvis Bay were just as striking. 


\section{Predation, disturbance and community structure}

The 3 most commonly cited influences on community structure in soft sediments are competition, predation and disturbance. Amensalistic interactions are also common. All have been shown to be important in various systems, but none have individually proven pivotal, and a generalised paradigm for soft-sediment community structure has not been successfully formulated. Thistle (1981) stated that a criterion for the disturbance model of soft-bottom community structure was that colonisers would exploit the early phase of recovery of a disturbed patch and ought to become disproportionately abundant during the early phases of recolonisation. To utilise this criterion, it is necessary to have known undisturbed patches by which background abundance can be determined. This condition is most likely to be met in studies of recovery after single or simulated disturbances. We had no comparable area that we were certain was undisturbed and could therefore not ascertain what 'normal' abundances might be in undisturbed patches. The earliest samples collected were at Walvis Bay intertidal, 1 wk after the exclosures were erected. Although differences in abundance were already apparent between treatments for some macrofaunal species, no species declined drastically in exclosures at a later stage. This suggests that competitive exclusion was not a significant force during succession. No macrofaunal species became locally extinct within exclosures, except when a similar decline was evident in control areas, indicating causes other than treatment. Such local extinction is postulated by Thistle (1981) as the second criterion for accepting that communities are organised by disturbance, as proposed by Grassle \& Sanders (1973). While disturbance by flamingos did affect the benthic community, it seems unlikely that any species or guild of species was dependent on these disturbances for survival in the systems studied. Capitella capitata in particular is well documented as an opportunistic, rapid coloniser of disturbed sediments (e.g. Arntz 1977). In this light, its persistence and increased abundance inside the exclosures was surprising. Clearly there was no tendency towards exclusion of this species from caged areas by other species. It is possible that in the absence of flamingos, other forms of disturbance were adequate for C. capitata to persist within the exclosures. The sand shark Rhinobatos annulatus has been shown to be an important predator and bioturbator in other lagoon systems (Harris et al. 1988). $R$. annulatus was seasonally abundant in both the lagoons in this study. At Sandwich Harbour, the diamond-shaped depressions left by sand sharks were frequently visible. At Walvis Bay, this was not as apparent, possibly because more intense disturbance by flamingos obscured signs of sand shark feeding pits Depressions, possibly indicative of sand shark feeding, were frequently visible in the tube mats in the subtidal exclosures. $R$. annulatus feeds mostly on crustaceans, selectively avoiding polychaetes (Harris et al. 1988). Predation by this and other species could have facilitated the persistence of $C$. capitata in the cages.

A second possibility is that Capitella capitata despite being a coloniser, is able to compete successfully with other benthic fauna and can persist in patches after disturbance has ceased. This is particularly possible since the sediment at both sites had low oxygen content, and Arntz (1977) has shown that $C$. capitata can thrive under these conditions, although $C$. capitata populations in his exclosures only rose after most other fauna died. C. capitata are also known to thrive in areas of high organic content, in this study both numbers of $C$. capitata and organic content of the sediment were higher in exclosures than controls at Walvis Bay subtidal. In the intertidal area, organic content was lower in exclosures than in controls, and $C$ capitata abundance failed to respond to caging.

Finally, it is possible that competition is not a strong organising force in the benthos of these lagoons, and species which might be excluded from patches in systems where competition is more important are not affected at Walvis Bay or Sandwich Harbour

Competition is commonly held to be most intense between closely related species or between those species which utilise resources in similar ways, although this does not necessarily apply to competition for space (e.g. Virnstein 1977). Accordingly, any changes in community structure due to competition should be most obviously manifested among such species and most studies of competition concentrate on these species. In the present experiment, 2 species of congeneric tube-building amphipod co-occurred at all 3 sites. Contrary to what competition theory would predict, the density of both species increased at all sites within exclosures. Capitella capitata, a tube-building polychaete, was also found in higher densities inside exclosures than in control areas. The tubes of all these species were apparently interspersed; however, samples were not examined for potential small-scale separation between species, as described by the spacing hypothesis of Wilson (1983).

There was also an overall decline in macrofaunal abundance towards the end of the experiment, which may have obscured competitive interactions that might have become evident if high faunal densities had been maintained for longer. Peterson (1979), after reviewing caging experiments, concluded that the lack of competitive exclusion in soft-sediment studies was not an artifact of the short duration of the experiments, although some of them lasted only 3 to 6 mo 
At Walvis Bay subtidal, where macrofaunal densities were highest, densities of macrofauna remained high for approximately 8 mo before declining in all treatments. It is thus unlikely that the potential for competitive exclusion was not realised purely because populations were not maintained at high densities for long enough

Peterson (1979) has postulated that one reason for the absence of competitive exclusion in soft sediments is that soft sediments offer reduced opportunities for interference competition; however, he considered primarily the mechanisms of interference that are common to rocky shores, such as overgrowth of one species by another Infaunal organisms have the potential to substantially alter the character of the sediment, particularly at the surface. Negative interactions between species have been documented several times on this basis. Among these are trophic group amensalism (Rhoads \& Young 1970) and negative effects between burrowers and tube-builders (Woodin 1974, Hulberg \& Oliver 1980). Although these interactions are likely to be amensalistic rather than competitive (since there is no identifiable resource being competed for), they are a result of interference mechanisms. During this study, species that were negatively affected by exclosures included a large suspension feeder, Dosinia lupinus, and a large, burrowing carnivore, Cerebratulus fuscus. Hence both forms of amensalism discussed above could have been operating in this experiment. However these responses were not statistically significant. Furthermore, 2 small suspension feeders, the unidentified bivalve and the sabellid polychaete Desdemona ornata, increased abundance inside exclosures at 2 sites, further indicating the weakness of any amensalistic interactions that may have occurred.

The clearest pattern to emerge from the study was thus the increase in density of most species when a major predator, the greater flamingo, was excluded. Despite this increase, the proportions of the species hardly changed, no species disappeared from the exclosures, and only 1 species significantly declined in abundance. All these lines of evidence point to competition being of little importance in controlling community structure

Acknowledgements. Dr A. Williams and the staff of Walvis Bay Nature Conservation provided lab space and much logistical support. Namibian Nature Conservation allowed us to work at Sandwich Harbour and use the accommodation there. We thank all our field assistants, too numerous to name, who volunteered their time and effort. The project was funded by the Foundation for Research Development, and by a very generous donation from Walvis Bay Salt Refineries.

\section{LITERATURE CITED}

Alongi DM (1985) The effect of physical disturbance on population dynamics and trophic interactions among microbes and meiofauna. J Mar Res 43:351-364

Anonymous (1989) A study of some of the physical and biotic processes affecting dredging within the Walvis Bay lagoon. CSIR report

Arntz WE (1977) Results and problems of an 'unsuccessful benthos cage predation experiment (Western Baltic). In Keegan BF, Ceidigh PO, Boaden PJS (eds) Biology of benthic organisms. Pergamon Press, New York, p 31-44

Baird D, Evans PR, Milne $H$, Pienkowski MW (1985) Utilization by shorebirds of benthic invertebrate production in intertidal areas. Oceanogr Mar Biol Annu Rev 23:573-597

Bell SS (1980) Melofauna-macrofauna interactions in a high salt marsh habitat. Ecol Monogr 50(4):487-505

Bengtson SA (1976) Effect of burd predation on lumbricid populations. Oikos 27:9-12

Bildstein KL. Frederick PC, Spalding MG (1991) Feeding patterns and agressive behaviour in juvenile and adult American flamingos. Condor 93:916-925

Black R, Peterson CH (1988) Absence of preemption and interference competition for space between large suspension-feeding bivalves and smaller infaunal invertebrates J Exp Mar Biol Ecol 120:183-198

Brey $\mathrm{T}$ (1991) The relative importance of biological and phys ical disturbance: an example from intertidal and subtidal sandy bottom communities. Estuar Coast Shelf Sci 33 $339-360$

Brown L (1959) The mystery of the flamingos. Country Life Ltd, London

Connell JH (1972) Community interactions on marine rocky intertidal shores. Annu Rev Ecol Syst 3:169-192

Dayton PK (1984) Processes structuring some marine communities: are they general? In: Strong DR, Simberloff LGA Thistle AB (eds) Ecological communities: conceptual issues and the evidence. Princeton University Press Princeton, NJ, p 181-197

Freund RJ, Littell RC, Spector PC (1986) SAS systems for linear models. SAS Institute Inc, Cary, NC

Frid CLJ, James R (1988) The role of epibenthic predators in structuring the marine invertebrate community of a British coastal salt marsh. Neth J Sea Res 23(3):307-314

Glassom D. Branch GM (1997) The impact of predation by greater flamingos Phoenicopterus ruber on the meiofauna microflora, and sediment properties of two southern African lagoons. Mar Ecol Prog Ser (in press)

Grassle JF, Sanders HL (1973) Life histories and the role of disturbance. Deep Sea Res 20:643-659

Hall SJ, Raffaelli DJ, Basford DJ, Robertson MR (1990a) The importance of flatfish predation and disturbance on marine benthos: an experiment with dab Limanda limanda (L). J Exp Mar Biol Ecol 136:65-76

Hall SJ, Raffaell DJ, Turrell WR (1990b) Predator-caging experments in marme systems: a reexamination of thelr value. Am Nat 136(5):657-672

Harris SA, Bennett BA, Branch GM (1988) An assessment of the sand shark Rhinobatus annulatus as a predator in Langebaan lagoon. S Afr J Mar Sci 7:153-159

Hockey PAR, Bosman AL (1983) Conservation-management of the Walvis Bay lagoon with special reference to its importance as a bird habitat. Report submitted to the Association of Round Tables of South Africa, Walvis Bay section

Hulberg LW, Oliver JS (1980) Caging manipulations in marine soft-bottom communities -importance of animal 
interactions on sedimentary habitat modifications. Can J Fish Aquat Sci 37:1130-1139

Hurlbert SH, Chang CCY (1983) Effects of grazing by the Andean flamingo (Phoenicoparrus andinus). Proc Natl Acad Sci USA 80:4766-4769

Jenkin PM (1957) Filter feeding of flamingoes. Philos Trans $R$ Soc Lond B Biol Sci 240:406-493

Johnson RG (1970) Variations in diversity within benthic marine communities. Am Nat 104:285-300

Kneib RT (1988) Testing for indirect effects of predation in an intertidal soft-bottom community. Ecology 69(6): $1795-1805$

Menge BA, Sutherland JP (1987) Community regulation: variation in disturbance, competition, and predation in relation to environmental stress and recruitment. Am Nat $130(5): 730-757$

Oliver JS, Kvitek RG, Slattery PN (1985) Walrus feeding disturbance: scavenging habits and recolonisation of the Bering Sea benthos. J Exp Mar Biol Ecol 91:233-246

Paine RT (1974) Intertidal community structure: experimental studies on the relationship between a dominant competitor and its principal predator. Oecologia 41:245-272

Peterson CH (1977) Competitive organization of the softbottom macrobenthic communities of southern California lagoons. Mar Biol 43:343-359

Peterson CH (1979) Predation, competitive exclusion and diversity in the soft-sediment benthic communities of estuaries and lagoons. In: Livingston RJ (ed) Ecological processes in coastal and marine systems. Plenum Publishung. New York, p 233-264

Quammen ML (1981) Use of exclosures in studies of predation by shorebirds on intertidal mudflats. Auk 98:812-817

Quammen ML (1984) Predation by shorebirds, fish and crabs on invertebrates in intertidal mudflats: an experimental test. Ecology 65(2):529-537

Raffaelli D, Milne H (1987) An experimental investigation of the effects of shorebird and flatfish predation on estuanne invertebrates. Estuar Coast Shelf Sci 24:1-13

Reidenauer JA, Thistle D (1981) Response of a soft-bottom harpacticoid community to stingray (Dasyatis sabina) disturbance. Mar Biol 65:261-267

This article was submitted to the editor
Reise K (1978) Experiments on epibenthic predation in the Wadden Sea. Helgol Meersunters 30:263-271

Reise K (1985) Tidal flat ecology. Springer-Verlag, Berlin

Rhoads DC, Young DK (1970) The influence of deposit feeding organisms on sediment stability and community trophic structure. J Mar Res 28(2):150-178

Thistle D (1981) Natural physical disturbances and communities. Mar Ecol Prog Ser 6:223-228

Thrush SF (1986) Community structure on the floor of a sea lough: are large epibenthic predators important? J Exp Mar Biol Ecol 104:171-183

Thrush SF, Pridmore JE, Hewitt JE, Cummings VJ (1991) Impact of ray feeding disturbances on sandflat macrobenthos: do communities dominated by polychaetes or shellfish respond differently? Mar Ecol Prog Ser 69:245-292

Underwood AJ (1981) Techniques of analysis of variance in experimental marine biology and ecology. Oceanogr Mar Biol Annu Rev 19:513-605

Van Blaricom GR (1982) Experimental analyses of structural regulation in a marine sand community exposed to oceanic swell. Ecol Monogr 52(3):283-305

Virnstein RW (1977) The importance of predation by crabs and fishes on benthic infauna in Chesapeake Bay. Ecology $58: 1199-1217$

Virnstein RW (1978) Predator caging experiments in soft sediments: caution advised. In: Wiley ML (ed) Estuarine interactions. Academic Press, New York, p 261-273

Webb DG, Parsons TR (1991) Impact of predation-disturbance by large epifauna on sediment-dwelling harpacticoid copepods: field experiments in a subtidal seagrass bed. Mar Biol 109:485-491

Wilson HW Jr (1983) The role of density dependence in a marine infaunal community. Ecology 64(2):295-306

Wilson HW Jr (1989) Predation and the mediation of intraspecific competition in an infaunal community in the Bay of Fundy. J Exp Mar Biol Ecol 132:221-245

Woodin SA (1974) Polychaete abundance patterns in a marine soft-sediment environment: the importance of biological interactions. Ecol Monogr 44:171-187

Zar JH (1984) Biostatistical analysis, 2nd edn. Prentice-Hall Inc, Englewood Cliffs, NJ

Manuscript first received: October 5, 1993

Revised version accepted: December 10, 1996 